\title{
Helminths of the Lizard Salvator merianae (Squamata, Teiidae) in the Caatinga, Northeastern Brazil
}

\author{
A. A. M. Teixeira ${ }^{a}$, S. V. Brito ${ }^{b}$, D. A. Teles ${ }^{a}$, S. C. Ribeiro, J. A. Araujo-Filho ${ }^{a}$, V. F. Lima , \\ A. M. A. Pereira and W. O. Almeida $^{e}$
}

\begin{abstract}
aPrograma de Pós-graduação em Ciências Biológicas (Zoologia), Departamento de Sistemática e Ecologia - DSE, Centro de Ciências Exatas e da Natureza - CCEN, Universidade Federal da Paraíba - UFPB, Cidade Universitária, Campus I, CEP 58059-900, João Pessoa, PB, Brazil

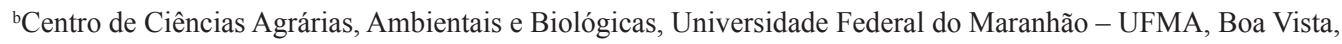
CEP 65500-000, Chapadinha, MA, Brazil

'Instituto de Formação de Educadores - IFE, Universidade Federal do Cariri - UFCA, Rua Olegário Emílio de Araújo, s/n, Campus Brejo Santo, CEP 63260-000, Brejo Santo, CE, Brazil

dPrograma de Pós-graduação em Bioprospecção Molecular, Departamento de Química Biológica, Universidade Regional do Cariri - URCA, Rua Cel. Antônio Luiz, 1161, Campus do Pimenta, CEP 63105-000, Crato, CE, Brazil

'Departamento de Ciências Biológicas, Universidade Regional do Cariri - URCA, Rua Cel. Antônio Luiz, 1161, Campus do Pimenta, CEP 63105-000, Crato, CE, Brazil

*e-mail: adoniasteixeira01@gmail.com
\end{abstract}

Received: August 31, 2015 - Accepted: February 3, 2016 - Distributed: May 31, 2017

(With 1 figure)

\begin{abstract}
The lizard Salvator merianae is a widely distributed species in South America, occurring from southern Amazonia to the eastern Andes and northern Patagonia. Studies on the parasitic fauna of this lizard have revealed that it is a host for helminths in various Brazilian biomes. The present work provides new parasitological data on the gastrointestinal nematodes associated with the lizard $S$. merianae. Sixteen specimens were analyzed from nine different locations in a semi-arid region in northeastern Brazil. Five species of nematodes were identified. Oswaldofilaria petersi was first recorded as a parasite of the $S$. merianae, thus increasing the knowledge of the fauna of parasites that infect large Neotropical lizards.
\end{abstract}

Keywords: parasitism, nematode, Oswaldofilaria petersi, Brazilian semiarid.

\section{Helmintos do lagarto Salvator merianae (Squamata, Teiidae) na Caatinga, Nordeste do Brasil}

\section{Resumo}

O lagarto Salvator merianae é uma espécie bem distribuída na América do Sul, ocorrendo do sul da Amazônia até o leste dos Andes e norte da Patagônia. Estudos com a fauna parasitária desse lagarto revelaram que ele hospeda helmintos em vários biomas brasileiros. O presente trabalho fornece novo dado parasitológico sobre nematoda gastrointestinal associado ao lagarto $S$. merianae. Dezesseis amostras foram analisadas a partir de nove localidades diferentes na região semiárida do nordeste do Brasil. Foram identificadas cinco espécies de nematóide. Oswaldofilaria petersi foi registrado pela primeira vez parasitando $S$. merianae, aumentando assim o conhecimento da fauna de parasitas que infectam grandes lagartos neotropicais.

Palavras-chave: parasitismo, nematoda, Oswaldofilaria petersi, semiárido do Brasil.

\section{Introduction}

The lizard Salvator merianae (Dumeril and Bibron, 1839) is a widely distributed species in South America (Ávila-Pires, 1995), occurring from southern Amazonia to the eastern Andes and northern Patagonia (Fitzgerald et al., 1999). The species has also been introduced by humans in the Parque Nacional de Fernando de Noronha, Brazil

(Homewood, 1995) and central-west Florida, USA (Mazzotti et al., 2014). It has an omnivorous diet consisting of arthropods, mostly the orders Coleoptera, Hymenoptera, Orthoptera and Araneae (Kiefer and Sazima, 2002), small vertebrates, birds, rodents, amphibians, lizards, turtles eggs (Presch, 1973; Sazima and Haddad, 1992), and fruits of 
plants of the families Arecaceae, Moraceae, Musaceae, and Solanaceae (Kiefer and Sazima, 2002; Castro and Galetti, 2004; Colli, 2004). The ingestion of the fruits acts as a seed dispersal mechanism (Castro and Galetti, 2004).

Studies on the parasitic fauna of $S$. merianae have revealed that it is a host for helminths in various Brazilian biomes: Cruzia sp. in areas of the Caatinga, in the Brazilian semiarid (Brito et al., 2014a); Cruzia travassosi Khalil and Vogelsang, 1932 in areas of the Amazon Forest, Cerrado and Pantanal (Ávila et al., 2010, 2011; Ávila and Silva, 2011); Diaphanocephalus galeatus (Rudolphi, 1819) in areas of coastal biomes in the Archipelago of Fernando de Noronha and the Amazon Forest, Cerrado and Pantanal (Ramalho et al., 2009; Ávila et al., 2010; Ávila and Silva, 2011); Physaloptera tupinambae Pereira, Alves, Rocha, Souza Lima and Luque, 2012 and P. bainae Pereira, Alves, Rocha, Souza Lima and Luque, 2014 in the municipality of Juiz de Fora - MG in areas of the Atlantic Forest (Pereira et al., 2012, 2014); P. lutzi Cristofaro, Guimarães and Rodrigues, 1976 in areas of the Caatinga, in the Brazilian semiarid (Brito et al., 2014b); P. retusa Rudolphi, 1819 in the Amazon Forest, Cerrado and Pantanal (Ávila and Silva, 2011); Spinicauda spinicauda (Olfers, 1819) in coastal biomes, and the Amazon Forest, Cerrado and Pantanal (Ramalho et al., 2009; Ávila and Silva, 2011); and a species of Cestoda not identified, Oochoristica sp. in coastal biomes in the Archipelago of Fernando de Noronha (Ramalho et al., 2009).

Studies on parasite-host relations are one of the factors responsible for the comprehension of variations that occur in the population dynamics of the structures of the community of vertebrates (Peters and Donoso-Barros, 1970). Infections by parasite influence the control of the population of the their hosts, causing damage to the infected organs (Almeida et al., 2008), alterations in the functioning of metabolism (Dare and Forbes, 2008), changes in sexual selection (Kose and Møller, 1999), diminution of reproductive performance (Hudson and Greenman, 1998) and modifications in the interspecific competition between hosts (Lafferty, 1999) and in predator-prey relations (Booth et al., 1993).

The aim of the present work was to enrich the existing knowledge about helminth parasites associated with $S$. merianae in northeastern Brazil by analyzing specimens of Caatinga, northeastern Brazil.

\section{Material and Methods}

The specimens of $S$. merianae used in this parasitological study derived from the Herpetological Collection of the Regional University of Cariri, and originated in nine municipalities in northeastern Brazil: Aiuaba, Antonina do Norte, Barro, Farias Brito, Juazeiro do Norte, Santa Quiteria and Várzea Alegre in the state of Ceará, Exu and Serrita in the state of Pernambuco (Figure 1). The above regions are part of the Caatinga biome, which is, for the most part, a hot and semiarid climate with a mean annual temperature of $26^{\circ} \mathrm{C}$ (Nimer, 1989). The Caatinga biome also shows an evident seasonality, with a mean annual rainfall of less than $1,000 \mathrm{~mm}$, where it is distributed in a period ranging from three to six months (Andrade-Lima, 1981).

The lizards were weighed with a precision $(0.01)$ balance (SHIMADZU-BL3200H), and snout-vent length (SVL) was measured with a tape measure $(\mathrm{mm})$. They were then dissected, and their digestive and respiratory tracts were removed for analysis under a stereomicroscope.

The nematodes found were counted and preserved in bottles with $70 \%$ ethanol for later identification of the species. The nematodes were cleared using lactophenol, mounted on temporary slides, analyzed with a microscope and identified through the literature (Pereira et al., 2012, 2014; Vicente et al., 1993). Subsequently, they were deposited in the Parasitological Collection of the Regional University of Cariri (URCA-P: 444-466).

\section{Results}

Sixteen lizards (S. merianae) were analyzed (SVL: $287.50 \mathrm{~mm} \pm 85.40 \mathrm{~mm}$ ): seven males (SVL: $311.60 \mathrm{~mm}$ $\pm 65.70 \mathrm{~mm}$ ) (five adults (SVL: $343.20 \mathrm{~mm} \pm 34.55 \mathrm{~mm}$ ) and two juveniles (SVL: $190.00 \mathrm{~mm}$ and $275.00 \mathrm{~mm}$ )) and six females (SVL: $317.00 \mathrm{~mm} \pm 37.20 \mathrm{~mm}$ ) (four adults (SVL: $337.00 \mathrm{~mm} \pm 35.50 \mathrm{~mm}$ ) and two juveniles (SVL: $264.00 \mathrm{~mm}$ and $290.00 \mathrm{~mm}$ )). Of all the lizards analyzed, only two were not parasitized.

Five species of nematodes were identified (Table 1): C. travassosi; D. galeatus; Oswaldofilaria petersi Bain and Sulahian, 1974; P. lutzi and Spinicauda spinicauda.

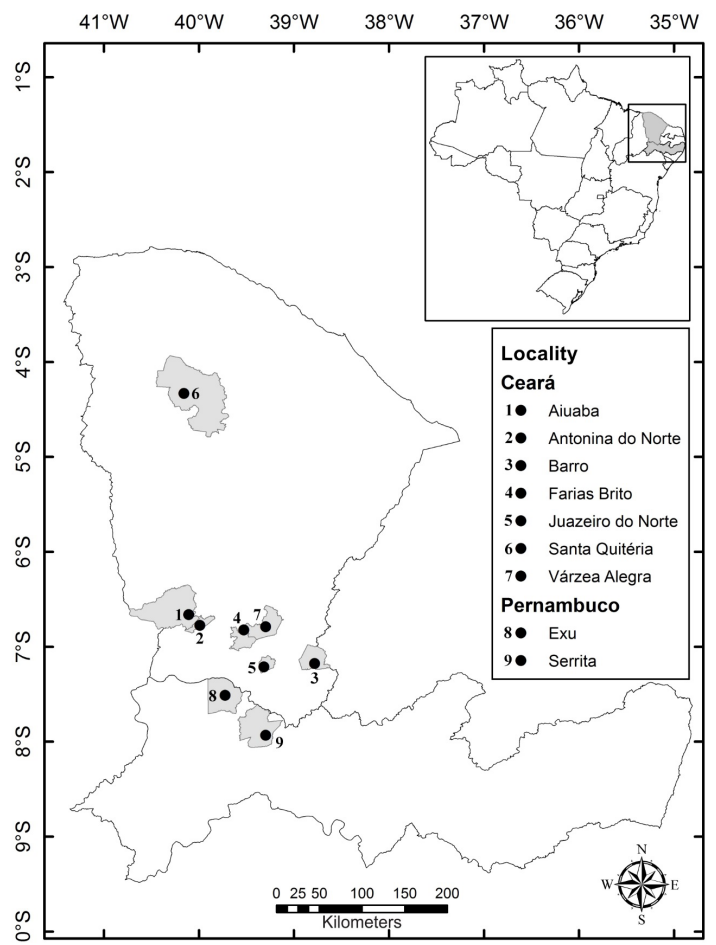

Figure 1. Places in Brazil where the analyzed lizards (Salvator merianae) were collected. 
Table 1. Parasitological data from populations of Salvator merianae.

\begin{tabular}{|c|c|c|c|c|c|}
\hline Locality (n) & SVL (mm) & Nematode & Infection Cycle & Infection (Range) & Site of infection \\
\hline \multirow[t]{2}{*}{ Aiuaba-CE (1) } & 345.00 & D. galeatus & monoxenous & 5.00 & intestine \\
\hline & & P. lutzi & heteroxenous & 364.00 & stomach, intestine \\
\hline \multirow{4}{*}{$\begin{array}{l}\text { Antonina do } \\
\text { Norte-CE (1) }\end{array}$} & 275.00 & D. galeatus & monoxenous & 57.00 & intestine \\
\hline & & O. petersi & heteroxenous & 3.00 & intestine \\
\hline & & P. lutzi & heteroxenous & 52.00 & stomach \\
\hline & & S. spinicauda & monoxenous & 17.00 & intestine \\
\hline \multirow[t]{3}{*}{ Barro-CE (1) } & 264.00 & D. galeatus & monoxenous & 6.00 & intestine \\
\hline & & P. lutzi & heteroxenous & 43.00 & stomach \\
\hline & & S. spinicauda & monoxenous & 4.00 & intestine \\
\hline \multirow[t]{2}{*}{ Exu-PE (1) } & 373.00 & P. lutzi & heteroxenous & 28.00 & stomach \\
\hline & & S. spinicauda & monoxenous & 6.00 & intestine \\
\hline \multirow{3}{*}{$\begin{array}{l}\text { Farias } \\
\text { Brito-CE (2) }\end{array}$} & 327.00 and 328.00 & D. galeatus & monoxenous & 11.00 and 31.00 & intestine \\
\hline & & P. lutzi & heteroxenous & 13.00 and 25.00 & stomach \\
\hline & & S. spinicauda & monoxenous & 4.00 and 12.00 & intestine \\
\hline \multirow{3}{*}{$\begin{array}{l}\text { Juazeiro do } \\
\text { Norte-CE (3) }\end{array}$} & $315.00 \pm 25.00$ & D. galeatus & monoxenous & 5.00 & intestine \\
\hline & & P. lutzi & heteroxenous & $26.00 \pm 13.80$ & stomach \\
\hline & & S. spinicauda & monoxenous & $9.70 \pm 7.50$ & intestine \\
\hline \multirow[t]{2}{*}{ Serrita-PE (2) } & 320.00 and 400.00 & C. travassosi & monoxenous & 4.00 & intestine \\
\hline & & D. galeatus & monoxenous & 30.00 & intestine \\
\hline Várzea & $183.00 \pm 95.00$ & C. travassosi & monoxenous & 6.00 & intestine \\
\hline Alegre-CE (5) & & P. lutzi & heteroxenous & 13.00 & intestine \\
\hline
\end{tabular}

\section{Discussion}

In South America, the nematode genus Cruzia Travassos, 1917 has been well reported parasitizing lizards of the Teiidae family (Ávila and Silva, 2010): C. fuelleborni Khalil and Vogelsang, 1930 described from Tupinambis teguixin (Linnaeus, 1758) (Vicente et al., 1993); C. tentaculata (Rudolphi, 1819), registered for T. teguixin in Montevidéu, Uruguai (Lent and Freitas, 1948); C. travassosi infecting $S$. merianae in three states of the Midwest of Brazil (Ávila et al., 2010; Ávila and Silva, 2011; Ávila et al., 2011); Cruzia sp. parasitizing T. teguixin (Vicente et al., 1993), S. merianae and Ameivula ocellifera (Spix, 1825) (Brito et al., 2014a, b) in Brazil.

There are three species of the genus Diaphanocephalus Diesing, 1851 in Brazil: D. diesingi Freitas and Lent, 1938 parasitizing the small intestine of T. teguixin in Pará State (Vicente et al., 1993); D. jacuruxi Alho, 1965 which was first recorded in Dracaena guianensis Daudin, 1801 (Vicente et al., 1993); and D. galeatus, infecting T. teguixin (Vicente et al., 1993) and S. merianae (Ávila, 2009; Ramalho et al., 2009; Ávila and Silva, 2010, 2011; Ávila et al., 2010).

Nematodes of the family Onchocercidae are heteroxenous and grouped into eight subfamilies, in which Oswaldofilariinae stand out as parasitized reptiles (Anderson, 2000). In India and Sri Lanka Lanka, Conispiculum flavescens (Castellani and Willey, 1905) infects the connective tissues in the garden lizard Calotes versicolor (Daudin, 1802). In South
America, O. belemensis Bain and Sulahian, 1974 parasitize the heart, aorta and vena cava of D. guianensis. In Brazil, O. azevedoi Bain, 1974 parasitize the cavity of the lizard Polychrus marmoratus (Linnaeus, 1758); O. bacillaris (Molin, 1858) occurs in the thoracic muscles and lungs of the Caiman crocodilus (Linnaeus, 1758), C. sclerops (Duméril and Bribon, 1836) and Champsa nigra (Spix, 1825); O. brevicaudata (Rhodhain and Vuylsteke, 1937) infect the Iguana iguana (Linnaeus, 1758); O. spinosa Bain and Sulahian, 1974 parasitize the Scincidae Mabuya nigropunctata (Spix, 1825); and O. petersi has already been found to infect the mesentery, intestine and thigh muscles of T. teguixin (Vicente et al., 1993; Anderson, 2000).

In the present study, we recorded the first occurrence of $O$. petersi parasitizing $S$. merianae, and the second occurrence of this nematode parasitizing the Teiidae family in Brazil.

Nematodes of the genus Physaloptera Rudolphi, 1819 are heteroxenous and occur in the stomachs of various vertebrates (Anderson, 2000), especially reptiles and amphibians in South America (Ávila and Silva, 2010; Campiao et al., 2014). Salvator merianae has been well reported as a host for the nematodes of the family Physalopteridae in Brazil, as follow: P. bainae (Pereira et al., 2014); P. lutzi (Brito et al., 2014b); P. retusa (Ávila and Silva, 2011), and P. tupinambae (Pereira et al., 2012). In addition, P. lutzi also infects the stomach of the following lizards: Ameiva ameiva (Linnaeus, 1758) (Ribas et al., 1998); C. abaetensis Dias, Rocha and Vrcibradic, 2002 (Dias et al., 2005); 
C. littoralis (Rocha, Bamberg Araújo and Vrcibradic, 2000) (Ribas et al., 1995); Enyalius bilineatus Duméril and Bibron, 1837 (Vrcibradic et al., 2007); Eurolophosaurus nanuzae (Rodrigues, 1981) (Fontes et al., 2003); Tropidurus itambere (Rodrigues, 1987) (Van Sluys et al., 1994); T. torquatus (Wied-Neuwied, 1820) (Vrcibradic et al., 2000); T. oreadicus Rodrigues, 1987 (Ávila et al., 2011).

According to Anderson (2000), nematodes of the family Physalopteridae use a wide variety of insects as intermediate hosts. Possibly, amphibians may also represent a group of intermediate hosts for these helminthes, since it is common to find larval forms of Physaloptera sp. in anurans from South America (Campiao et al., 2014).

Thus, knowing that diet is commonly linked to the mechanisms by which heteroxenous parasites infect their hosts (Martin et al., 2005), the predominance of nematodes belonging to the family Physalopteridae registered for $S$. merianae may be related to the vastly diverse diet of this lizard.

Parasites of the subfamily Spinicaudinae are monoxenous (eggs in the infectious stage are ingested by the host) and infect amphibians and reptiles (Anderson, 2000). In Madagascar, Spinicauda freitasi (Chabaud and Brygoo, 1960) and S. inglisi (Chabaud and Brygoo, 1960) occur together in the rectal tube of chameleons in that region (Petter, 1968). However, S. spinicauda is the only species found in South America, and infects A. ameiva in Rio de Janeiro and $S$. merianae in Ceará (Vicente et al., 1993), Mato Grosso (Ávila and Silva, 2011) and Fernando de Noronha in the state of Pernambuco (Ramalho et al., 2009) in Brazil.

The massive presence of species of nematodes infecting the lizard $S$. merianae, in contrast with the absence of other taxa of helminths (such as acanthocephalans, cestodes and trematodes), can be explained in the present observational study, through competitive exclusion (Holmes, 1973), where parasite competition for resources, would be the answer to infer why a taxon appears to be absent in the presence of others (Friggens and Brown, 2005).

Some juvenile lizards of $S$. merianae in the present study were not infected with nematodes or an abundance of parasites smaller than adult specimens. This can be explained by the fact that larger and older lizards tend to present a greater diversity of parasites, prevalence, intensity of infection and abundance due to long exposure time and contact with sources of infection (Vogel and Bundy, 1987; Cunha-Barros et al., 2003).

The data presented here serve to increase the knowledge of the fauna of gastrointestinal parasites associated with S. merianae. However, further studies need to be conducted with a larger sample to better understand the infection patterns of this lizard in the Neotropical region.

\section{Acknowledgements}

We are grateful to the Conselho Nacional de Desenvolvimento Científico e Tecnológico - CNPq (PQ-302429/2015-8) for the research grant awarded to W.O.Almeida, and D.A. Teles; to Coordenação de Aperfeiçoamento de Pessoal de Nível Superior-CAPES for the scholarship awarded to A.A.M. Teixeira, J.A. Araújo-Filho, V.F. Lima, A.M.A. Pereira; to Fundação Cearense de Apoio ao Desenvolvimento Científico e Tecnológico - FUNCAP for the scholarship awarded to S.V. Brito; to R.W. Ávila, curator of Coleção Herpetológica da Universidade Regional do Cariri (URCA $-\mathrm{H}$ ) for suggestions and revision taxonomic; H.F. Oliveira and D.O. Santana for the final artwork. Finally, we thank Proof-Reading-Service.com Ltda, for revision professional of English version of the manuscript.

\section{References}

ALMEIDA, W.O., GUEDES, T.B., FREIRE, E.M. and VASCONCELLOS, A., 2008. Pentastomid infection in Philodryas nattereri Steindachner, 1870 and Oxybelis aeneus (Wagler, 1824) (Squamata: Colubridae) in a caatinga of Northeastern Brazil. Brazilian Journal of Biology $=$ Revista Brasileira de Biologia, vol. 68, no. 1, pp. 193-197. http://dx.doi.org/10.1590/S151969842008000100028. PMid:18470397.

ANDERSON, R.C., 2000. Nematode parasites of vertebrates: their development and transmission. 2nd ed. New York: CABI Publishing. $650 \mathrm{p}$.

ANDRADE-LIMA, D., 1981. The Caatinga dominium. Revista Brasileira de Botanica. Brazilian Journal of Botany, vol. 4, pp. 149-153.

ÁVILA, R.W., 2009. Padrões de infecção por helmintos em comunidades de lagartos do Brasil Central. Botucatu: Universidade Estadual Paulista Júlio de Mesquita Filho, 215 p. Tese de Doutorado em Biologia Geral e Aplicada.

ÁVILA, R.W. and SILVA, R.J., 2010. Checklist of helminths from lizards and amphisbaenians (Reptilia, Squamata) of South America. The Journal of Venomous Animals and Toxins Including Tropical Diseases, vol. 16, no. 4, pp. 543-572. http://dx.doi. org/10.1590/S1678-91992010000400005.

ÁVILA, R.W. and SILVA, R.J., 2011. Helminths of lizards (Reptilia: Squamata) from Mato Grosso State, Brazil. Comparative Parasitology, vol. 78 , no. 1, pp. 129-139. http://dx.doi.org/10.1654/4473.1.

ÁVILA, R.W., CARDOSO, M.W., ODA, F.H. and SILVA, R.J., 2011. Helminths from Lizards (Reptilia: Squamata) at the Cerrado of Goiás State, Brazil. Comparative Parasitology, vol. 78, no. 1, pp. 120-128. http://dx.doi.org/10.1654/4472.1.

ÁVILA, R.W., SOUZA, F.L. and SILVA, R.J., 2010. Helminths from seven species of lizards (Reptilia: Squamata) at the Cerrado of Mato Grosso do Sul State, Brazil. Comparative Parasitology, vol. 77, no. 1, pp. 67-71. http://dx.doi.org/10.1654/4414.1.

ÁVILA-PIRES, T.C.S., 1995. Lizards of the Brazilian Amazonia (Reptilia: Squamata) (Zoologische Verhandelingen). Leiden: Nationaal Natuurhistorisch Museum. 299 p.

BOOTH, D.T., CLAYTON, D.H. and BLOCK, B.A., 1993. Experimental demonstration of the energetic cost of parasitism in free-ranging hosts. Proceedings of the Royal Society of London. Series B, Biological Sciences, vol. 253, no. 1337, pp. 125-129. http://dx.doi.org/10.1098/rspb.1993.0091.

BRITO, S.V., CORSO, G., ALMEIDA, A.M., FERREIRA, F.S., ALMEIDA, W.O., ANJOS, L.A., MESQUITA, D.O. and VASCONCELLOS, A., 2014b. Phylogeny and micro-habitats 
utilized by lizards determine the composition of their endoparasites in the semiarid Caatinga of Northeast Brazil. Parasitology Research, vol. 1, no. 10, pp. 3963-3972. PMid:25096534.

BRITO, S.V., FERREIRA, F.S., RIBEIRO, S.C., ANJOS, L.A., ALMEIDA, W.O., MESQUITA, D.O. and VASCONCELLOS, A., 2014a. Spatial-temporal variation of parasites in (Teiidae) and and (Tropiduridae) from Caatinga areas in northeastern Brazil. Parasitology Research, vol. 113, no. 3, pp. 1163-1169. http://dx.doi.org/10.1007/s00436-014-3754-7. PMid:24481899.

CAMPIAO, K.M., MORAIS, D.H., DIAS, O.T., AGUIAR, A., TOLEDO, G., TAVARES, L.E.R. and SILVA, R.J., 2014. Checklist of Helminth parasites of Amphibians from South America. Zootaxa, vol. 3843, no. 1, pp. 1-93. http://dx.doi.org/10.11646/ zootaxa.3843.1.1. PMid:25082165.

CASTRO, E.R. and GALETTI, M., 2004. Frugivoria e dispersão de sementes pelo lagarto teiú Tupinambis merianae (Reptilia: Teiidae). Papéis Avulsos de Zoologia, vol. 44, pp. 91-97. http:// dx.doi.org/10.1590/S0031-10492004000600001.

COLLI, G.R., 2004. Guia dos lagartos do Distrito Federal. Brasília: Universidade de Brasília.

CUNHA-BARROS, M., VAN SLUYS, M., VRCIBRADIC, D., GALDINO, C.A.B., HATANO, F.H. and ROCHA, C.F.D., 2003. Patterns of infestation by chigger mites in four diurnal lizard species from a restinga habitat (Jurubatiba) of Southeastern Brazil. Brazilian Journal of Biology $=$ Revista Brasileira de Biologia, vol. 63, no. 3, pp. 393-399. http://dx.doi.org/10.1590/ S1519-69842003000300005. PMid:14758698.

DARE, O.K. and FORBES, M.R., 2008. Rates of development in male and female wood frogs and patterns of parasitism by lung nematodes. Parasitology, vol. 135, no. 3, pp. 385-393. http://dx.doi.org/10.1017/S0031182007003836. PMid:17991306.

DIAS, E.J.R., VRCIBRADIC, D. and ROCHA, C.F.D., 2005. Endoparasites infecting two species of whiptail lizard (Cnemidophorus abaetensis and C. Ocellifer; Teiidae) in a restinga habitat of Northeastern Brazil. The Herpetological Journal, vol. 15, no. 2, pp. 133-137.

FITZGERALD, L.A., COOK, J.A. and AQUINO, A.L., 1999. Molecular phylogenetics and conservation of Tupinambis (Sauria: Teiidae). Copeia, vol. 1999, no. 4, pp. 894-905. http://dx.doi. org/10.2307/1447965

FONTES, A.F., VICENTE, J.J., KIEFER, M.C. and VAN SLUYS, M., 2003. Parasitism by helminthes in Eurolophosaurus nanuzae (Lacertilia: Tropiduridae) in an area of rocky outcrops in Minas Gerais state, southeastern Brazil. Journal of Herpetology, vol. 37, no. 4, pp. 736-741. http://dx.doi.org/10.1670/68-03A N N.

FRIGGENS, M.M. and BROWN, J.H., 2005. Niche partitioning in the cestode communities of two elasmobranchs. Oikos, vol. 108, no. 1, pp. 76-84. http://dx.doi.org/10.1111/j.0030-1299.2005.13275.x.

HOLMES, J.C., 1973. Site selection by parasitic helminthes: interspecific interactions, site segregation, and their importance to the development of helminth communities. Canadian Journal of Zoology, vol. 51, no. 3, pp. 333-347. http://dx.doi.org/10.1139/ z73-047. PMid:4581918.

HOMEWOOD, B., 1995. Tejus upset natural order in Brazilian sanctuary. New Scientist, vol. 18, no. 5, pp. 1-5.

HUDSON, P. and GREENMAN, J., 1998. Competition mediated by parasites: biological and theoretical progress. Trends in Ecology \& Evolution, vol. 13, no. 10, pp. 387-390. http://dx.doi.org/10.1016/ S0169-5347(98)01475-X. PMid:21238357.
KIEFER, M.C. and SAZIMA, I., 2002. Diet of juvenile tegu lizard Tupinambis merianae (Teiidae) in southeastern Brazil. Amphibia-Reptilia, vol. 23, pp. 105-108.

KOSE, M. and MØLLER, A.P., 1999. Sexual selection, feather breakage and parasites: the importance of white spots in the tail of the barn swallow. Behavioral Ecology and Sociobiology, vol. 45, no. 6, pp. 430-436. http://dx.doi.org/10.1007/s002650050581.

LAFFERTY, K.D., 1999. The evolution of trophic transmission. Parasitology Today (Personal Ed.), vol. 15, no. 3, pp. 111-115. http://dx.doi.org/10.1016/S0169-4758(99)01397-6. PMid:10322324.

MARTIN, J.E., LLORENTE, G.A., ROCA, V., CARRETERO, M.A., MONTORI, A., SANTOS, X. and ROMEU, R., 2005. Relationship between diet and helminths in Gallotia caesaris (Sauria: Lacertidae). Zoology (Jena, Germany), vol. 108, no. 2, pp. 121-130. http://dx.doi.org/10.1016/j.zool.2005.03.002. PMid:16351960

MAZZOTTI, F.J., MCEACHERN, M., ROCHFORD, M., REED, R.N., ECKLES, J.K., VINCI, J., EDWARDS, J. and WASILEWSKI, J., 2014. Tupinambis merianae as nest predators of crocodilians and turtles in Florida, USA. Biological Invasions, vol. 17, no. 1, pp. 47-50. http://dx.doi.org/10.1007/s10530-014-0730-1.

NIMER, E., 1989. Climatologia do Brasil. 2nd ed. Rio de Janeiro: Fundação IBGE/SUPREN.

PEREIRA, F.B., ALVES, P.V., ROCHA, B.M., DE SOUZA LIMA, S. and LUQUE, J.L., 2012. A new Physaloptera (Nematoda: Physalopteridae) parasite of Tupinambis merianae (Squamata: Teiidae) from Southeastern Brazil. The Journal of Parasitology, vol. 98, no. 6, pp. 1227-1235. http://dx.doi.org/10.1645/GE3159.1. PMid:22712869.

PEREIRA, F.B., ALVES, P.V., ROCHA, B.M., DE SOUZA LIMA, S. and LUQUE, J.L., 2014. Physaloptera bainae n. sp. (Nematoda: Physalopteridae) Parasitic in Salvator merianae (Squamata: Teiidae), with a Key to Physaloptera Species Parasitizing Reptiles from Brazil. The Journal of Parasitology, vol. 100, no. 2, pp. 221-227. http://dx.doi.org/10.1645/13-281.1. PMid:24171701.

PETERS, J.A. and DONOSO-BARROS, R., 1970. Catalogue of the neotropical squamata: part ii lizards and amphisbaenians. Washington: Smithsonian Institution/US National Museum. 293 p. Bulletin 297.

PETTER, A.J., 1968. Cycle évolutif de 2 espèces d'Heterakidae parasites de caméléons malgaches. Annales de Parasitologie Humaine et Comparee, vol. 43, no. 6, pp. 693-704. PMid:5714486.

PRESCH, W., 1973. A review of the tegu lizards genus Tupinambis (Sauria: Teiidae) from South America. Copeia, vol. 4, no. 4, pp. 740-746. http://dx.doi.org/10.2307/1443074.

RAMALHO, A.C.O., SILVA, R.J., SCHWARTZ, H.O. and PÉRES JUNIOR, A.K., 2009. Helminths from an introduced species (Tupinambis merianae), and two endemic species (Trachylepis atlantica and Amphisbaena ridleyi) from Fernando de Noronha archipelago, Brazil. The Journal of Parasitology, vol. 95, no. 4, pp. 1026-1028. http://dx.doi.org/10.1645/GE-1689.1

RIBAS, S.C., ROCHA, C.F.D., TEIXEIRA-FILHO, P.F. and VICENTE, J.J., 1995. Helminths (Nematoda) of the lizard Cnemidophorus ocellifer (Sauria: Teiidae): assessing the effect of rainfall, body size and sex in the nematode infection rates. Ciencia e Cultura, vol. 47, pp. 88-91.

RIBAS, S.C., ROCHA, C.F.D., TEIXEIRA-FILHO, P.F. and VICENTE, J.J., 1998. Nematode infection in two sympatric lizards (Tropidurus torquatus and Ameiva ameiva) with different foraging tactics. Amphibia-Reptilia, vol. 19, no. 3, pp. 323-330. http://dx.doi.org/10.1163/156853898X00232. 
SAZIMA, I. and HADDAD, C.F.B., 1992. Répteis da Serra do Japi. In: L.P.C. MORELLATO, ed. História Natural da Serra do Japi: ecologia e preservação de uma área florestal no sudeste do Brasil. Campinas: Universidade Estadual de Campinas/Fundação de Amparo à Pesquisa do Estado de São Paulo, pp. 212-235.

VAN SLUYS, M., ROCHA, C.F.D. and RIBAS, S.C., 1994. Nematodes infecting the lizard Tropidurus itambere in southeastern Brazil. Amphibia-Reptilia, vol. 15, no. 4, pp. 405-408. http:// dx.doi.org/10.1163/156853894X00443.

VICENTE, J.J., RODRIGUES, H.O., GOMES, D.C. and PINTO, R.M., 1993. Nematóides do Brasil. Parte III: Nematóides de Répteis. Revista Brasileira de Zoologia, vol. 10, no. 1, pp. 19-168. http:// dx.doi.org/10.1590/S0101-81751993000100003.
VOGEL, P. and BUNDY, D.A.P., 1987. Helminth parasites of Jamaican anoles (Reptilia: Iguanidae): variation in prevalence and intensity with host age and sex in a population of Anolis lineatopus. Parasitology, vol. 94, no. 2, pp. 399-404.

VRCIBRADIC, D., CUNHA-BARROS, M., VICENTE, J.J., GALDINO, C.A.C., HATANO, F.H., VAN SLUYS, M. and ROCHA, C.F.D., 2000. Nematode infection patterns in four sympatric lizards from a restinga habitat (Jurubatiba) in Rio de Janeiro state, southeastern Brazil. Amphibia-Reptilia, vol. 21, no. 3, pp. 307-316. http://dx.doi.org/10.1163/156853800507507.

VRCIBRADIC, D., VICENTE, J.J. and BURSEY, C., 2007. Helminths infecting the lizard Enyalius bilineatus (Iguanidae, Leiosaurinae), from an Atlantic Rainforest area in Espirito Santo state, southeastern Brazil. Amphibia-Reptilia, vol. 28, no. 1, pp. 166-169. http://dx.doi.org/10.1163/156853807779799009. 